\title{
Cytotoxic, Antimicrobial and Anti-oxidant Screening of Psidium Guajava Leaves Grown in Oman
}

\author{
Afaf M Weli*, Amna Al-Kaabi, Sadri Said, Amzad Hossain, MD Sohail Akhtar, Ahlam Al-Abri and Qasim Al- \\ Riyami
}

University of Nizwa, Sultanate of Oman, Oman

Submission: January 09, 2017; Published: February 06, 2017

*Corresponding author: Afaf M Weli, University of Nizwa, Sultanate of Oman, Tel: -92445457; Email: afaf@unizwa.edu.om

\begin{abstract}
Psidium guajava (guava) belongs to the family Myrtaceae, is a most important medicinal plant used in folk medicine to treat gastrointestinal, respiratory disturbances and used as anti-inflammatory medicine. The present study was carried out to evaluate the antioxidant, antimicrobial and cytotoxicity capacities of various crude extracts of the leaves of guava. Dried plant material macerated in ethanol gave crude extract that was Kupchan's partitioned into hexane, chloroform, and ethyl acetate fractions. The cytotoxicity activity was carried out by brine shrimp lethality bioassay and antimicrobial activity was determined by agar disc diffusion method against E. coli, P. aeruginosa and S. aurues using four different concentrations of each extract including 250, 500, 1000, and2000 $\mathrm{g} / \mathrm{ml}$. Cytotoxicity was estimated using brine shrimp test. 2, 2-Diphenyl-1picrylhydrazyl (DPPH) assay was used for radical scavenging analysis. All extracts did not show any cytotoxicity or antibacterial activity at any of the tested concentration but all extracts showed potent radical scavenging activity, the highest is seen with the hydro-alcoholic and ethyl acetate extracts.
\end{abstract}

Keywords: Gujava Psidium; Crude extracts; Antioxidant; Antimicrobial; Cytotoxicactivity; Oman

Abbreviations: GUAVA: Psidium Guajava; DDPH: 2, 2-Diphenyl-1-Picrylhydrazyl

\section{Introduction}

Guava (PsidiumguajavaL L inn.) is commonly known for its food and nutritional values throughout the world. The medicinal properties of guava fruit, leaf and other parts of the plant are also well known in traditional system of medicine since each part of guava tree possesses economic and medicinal value [1,2]. It is distributed in some Arabic countries; Saudi Arabia, Oman and Egypt [3-10]. The biochemical analyses of the crude extracts from leaves and fruits indicated the presence of different group of compounds such as flavonoids, tannins, phenols, triterpenes, saponins, carotenoids, lectins, vitamins, fiber and fatty acids $[4,11]$. This plant also contains sugar, resins and glycosides [12]. The literature survey reveals that no research has been done on Omani guava. Therefore the present study was to determine the antioxidant, antimicrobial and cytotoxic activity of different leaves crude extracts of guava native to Sultanate of Oman.

\section{Experimental}

\section{a. Materials}

Hexane, ethanol, chloroform and ethyl acetate were used in this experiment obtained Sigma-Aldrich Company, UK. The other necessary chemicals such as 2-diphenyl-1-picrylhydrazyl, (DPPH), sodium sulfate etc. was obtained from BDH, Germany. Gram positive bacteria (Staphylococcus aureus) and gram negative bacteria (Escherichia coli and Pseudomonas,) were from Biological Department, College of Art and Science, University of Nizwa. Filter paper discs of diameter $6 \mathrm{~mm}$ were obtained from Whatmann Company, catalogue number: 8174900. Nutrient ager and plastic Petri dishes were from SharlauChemie Company. Brine shrimp eggs (ARTEMIA CYSTS) were purchased from GOAQUA, Taiwan. Sea salt was obtained from Al-Qurum Muscat. All the glassware used in this present experiment was from Borosil, India.

\section{b. Instruments}

UV spectra were recorded on Thermo spectronic spectrophotometer (Great Britain, UK, Model No. Biomate) Ultra speck in methanol ( $\lambda$ max in $\mathrm{nm}$ ). Rotatory evaporator was used Yamato Rotary Evaporator, Model RE 801, Japan. Incubator used in this experiment obtained from Gen Lab Model: MINO/75F, Serial number: Y5K041. 


\section{c. Plant Material}

The leaves samples were collected from Alsharqia region Sultanate of Oman in October 2012. The fresh leave samples were packed instantly after harvesting. The samples were washed with tap water to remove the dust and other foreign particles. The plant was identified and confirmed by the Ministry of Agriculture and Fisheries.

\section{d. Extraction}

The samples were dried under shade at room temperature for 7 days. The dried samples (139.45g) were macerated in absolute ethanol (2L) for 7 days to give crude extract. The residue was suspended in ethanol/water mixture of 1:1 ratio then extracted successively with hexane, chloroform, and ethyl acetate. All solvents were later removed under vacuum using rotatory evaporator.

\section{e. Anti-bacterial test}

The antibacterial test was carried out by agar disc diffusion method [13]. Each extract was subjected to serial dilution technique, using dimethyl sulphoxide as a solvent to give Concentrations of 2000, 1000, 500, and $250 \mu \mathrm{g} / \mathrm{ml}$. Filter paper discs (6 $\mathrm{mm}$ diameter) were Impregnated with each concentration and placed on the agar plates inoculated with the bacteria. Negative controls were prepared using the same solvents employed to dissolve the samples. The plates were incubated micro aerobically at $37^{\circ} \mathrm{C}$ for $24 \mathrm{~h}$. Anti-bacterial activity was evaluated by measuring the diameter of the zones of inhibition against the tested bacteria. Each assay was done in triplicate.

\section{f. Brine shrimp test}

Brine shrimp (Artemiasalina Leach) larvae were used as indicator animal for preliminary cytotoxicity assay as described by McLaughlin and his group [14]. Shrimp larvae were hatched in artificial sea water prepared by dissolving $38 \mathrm{~g}$ of sea salt in distilled water (IL). The sea salt was placed in a small tank divided into two compartments by

Perforated polythene wall. About 50mg of GOAQUA brine shrimp eggs were sprinkled at covered chamber of duo compartment plastic container. The open compartment was illuminated to attract the shrimp larvae from the dark compartment once were hatched within 24 hours.

\section{g. Brine shrimp lethality test}

Solutions corresponding to 10, 100, 250, 500, 750 and 1000 $\mathrm{mcg} / \mathrm{ml}$ were prepared in six vials by serial dilution of the stock samples $(10 \mathrm{mg} / \mathrm{ml})$.Each experiment was done in triplicate. A total of 10 larvae were transferred in each vial and the solutions were diluted to $5 \mathrm{ml}$ by adding the artificial sea water. Mean percent mortalities of the larvae were calculated after 24 hours of exposure.

\section{h. Radical scavenging activity using DPPH method}

Free radical scavenging activity of different organic extracts was estimated as described by Blois [15] with minor modification. Four concentrations $(12.5,25,50,100$ and $200 \mathrm{ppm}$ equivalent to $12.5,25,50,100$ and $200 \mu \mathrm{g} / \mathrm{ml}$, respectively) were prepared for each extract (hexane, chloroform, ethyl acetate and hydroethanol. Four $\mathrm{ml}$ from each concentration were placed in a test tube to which one milliliter of $0.1 \mathrm{mM}$ methanol solution of DPPH (2,2-diphenyl-1-picrylhydrazyl) was added and shaken vigorously. After that all the test tubes were allowed to stand at $27{ }^{\circ} \mathrm{C}$ in dark place for $45 \mathrm{~min}$. The control was prepared in the same way but without adding extract. The absorbance of the prepared samples was measured using UV spectroscopy at $517 \mathrm{~nm}$. Radical scavenging activity of the tested crude extracts samples was estimated as the inhibition percentage and was calculated by using the following formula,

\section{Results and Discussion}

\section{a. Anti-microbial studies}

Previous studies which were done by Gonclaves, et al. [4] showed that there was some activity against S.aureus on the hexane extract, ethyl acetate extract, and methanol extract, but at high concentration of the three extract showed activity against E. coli and only the methanolic extract showed activity against Salmonella spp [4]. In a study that was done in Jordan, Psudium guava acetone extract showed sensitivity to Provenciastearti, Providenciarettgeri, Strepoccus group c, Staphylococcus auress, Candidealbicans. There was no activity against Proteus vulgaris, E. coli, Salmonella ssp, Pseudomonas aeruginosa, Streptoccusfaecalis found [12].

Penecilla, et al. [13] in the Philippines showed that the leaves acetone, ethanol and aqueous extracts had inhibitive activity but not for the hexane extract [13]. The four extracts hexane, chloroform, ethyl acetate and hydro alcoholic didn't show activity against gram +ve or gram -ve bacteria. This variation from other studies might be attributed to variation in environment, including day length, light intensity, ambient temperature, rainfall, soil or season of collection. All the crude extracts did not show any mortality at any concentration.

\section{b. Anti-oxidant activity}

The radical scavenging activity of the different crude extracts of guava leaves are presented in Figure 1. All extracts showed high radical scavenging activity at $50 \mu \mathrm{g} / \mathrm{ml}$ concentrations, the hydro-alcoholic and the chloroform extract exhibited more scavenging effects on free radicals than did the hexane and ethyl acetate extract. On the basis of the results obtained, guava Hydro-alcoholic and chloroform extracts the leaf of Guava can be used for a variety of beneficial chemo-preventive effects. However, further studies on the antioxidative components of guava extracts are required. 


\section{Global Journal of Pharmacy \& Pharmaceutical Sciences}

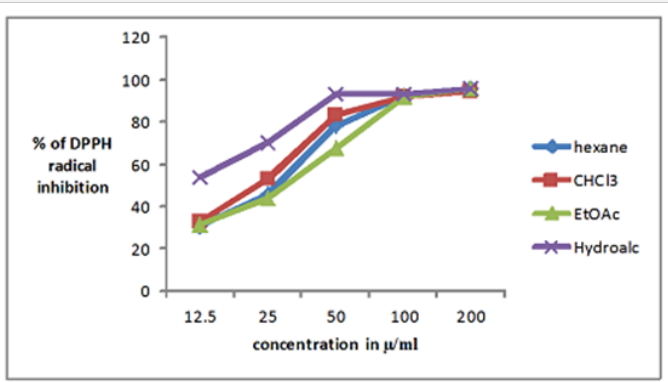

Figure 1: Anti-oxidant activity of psidium guajava extracts presented as percentage of DPPH inhibition.

\section{References}

1. Oliveros Belardo L, Smith RM, Robinson JM, Albano V (1986) Chemical study of the essential oil from the fruit peeling of Psidium guajava $\mathrm{L}$. Philippine Journal of Science 115(1): 1-21.

2. Kumar A (2012) Importance for life Psidium guava. International Journal of Research in Pharmaceutical and Biomedical Sciences (3): 137-143.

3. Joseph B (2011) Review on Nutritional, Medicinal and Pharmacological Properties of Guava. International Journal of Pharma and Bio Sciences 2(1): 53- 69.

4. Flávia Gonçalves A, Manoel Andrade Neto, José Bezerra NS, Andrew Macrae, Oscarina Viana de Sousa, et al. (2008) Anti-bacterial activity of GUAVA, Psidium Guajava Linnaeus, Leaf Extracts on Diarrhea-causing Enteric Bacteria Isolated From Seabob Shrimp, Xiphopenaeus Kroyeri (Heller). Rev Inst Med Trop Sao Paulo 50(1): 11-15.

5. Umar HY, Abolagba EO, Giroh DY, Lalabe BC (2011) Costs and Returns analysis Of Gum Arabic and Some Selected Tree Crops Production in Adamawa and Yobe States, Nigeria: An Implication for Poverty Alleviation. World Rural Observations 3(2): 49-54.
6. Ahmad Sattar Khan, Muhammad Rehman Gul Khan, Aman Ullah Malik, Basharat Ali Saleem, Ishtiaq Ahmad Rajwana, et al. (2011) Influence Of Defoliation And Deblossoming on the Vegetative and Reproductive Growth Of Guava (Psidium Guajava L). Pak J Bot 43(6): 2891-2899.

7. Shahina A Ghazanfar (1994) Hand Book of Arabian Medicinal Plant. CRC Press pp: 272.

8. Metwally AM, Omar AA, Harraz FM, El Sohafy SM (2010) Phytochemical investigation and anti-microbial activity of Psidium guajava $\mathrm{L}$ leaves. Pharmacogn Mag 6(23): 212-218.

9. Umedi L Yadava (1996) Guava Production in Georgia Under ColdProtection Structure. J Janick (ed), Progress in New Crops. ASHS Press. Virginia pp: 451-457.

10. Perácio Rafael Bueno Ferreira, Cíntia Sorandra Oliveira Mendes, Sarah Barbosa Reis, Cínthia Gracielly Rodrigues, Dario Alves de Oliveira, et al. (2011) Morphoanatomy, Histochemistry and Phytochemistry of Psidium guineense Sw(Myrtaceae) Leaves. Journal of Pharmacy Research 4(4): 942-944.

11. Adeyemi O Stephen, Akanji MA, Oguntoye SA (2009) Ethanolic leaf extract of Psidium guajava: Phytochemicaland trypanocidal activity in rats infected with Trypanosoma brucei brucei Journal of Medicinal Plants Research 3(5): 420-423.

12.Zhang WJ, Chen BT, Wang CY, Zhu QH, Mo ZX (2003) Mechanism of Quercetin an Anti-diarrheal Agent. Di Yi Gun Yi Da Xue Xue Bao 23(10): 1029-1031.

13. Gerard L Penecilla, Celia P Magno (2011) Anti-bacterial Activity of Extracts of Twelve Common Medicinal Plants from the Philippines. Journal of Medicinal Plant Research 5(16): 3975-3981.

14. Jerry L Mclaughlin, Lingling L Rogers, Jon E Anderson (1998) The use of biological assay to evaluate botanicals. Drug Information Journal 32: 513-524.

15. Marsden S Blois (1958) Anti-oxidant determination by the use of a stable free radical. Nature 181:1199-1200. 